\title{
Impacts of Different Tree Species of Different Sizes on Spatial Distribution of Herbaceous Plants in the Nigerian Guinea Savannah Ecological Zone
}

\author{
Toma Buba \\ Department of Biological Sciences, Faculty of Science, Abubakar Tafawa Balewa University, PMB 0248, Bauchi, Nigeria \\ Correspondence should be addressed to Toma Buba; tomabuba@yahoo.com
}

Received 19 June 2015; Revised 17 September 2015; Accepted 4 October 2015

Academic Editor: Artemi Cerda

Copyright @ 2015 Toma Buba. This is an open access article distributed under the Creative Commons Attribution License, which permits unrestricted use, distribution, and reproduction in any medium, provided the original work is properly cited.

\begin{abstract}
This study was aimed at finding the impacts of different tree species and individual trees of different sizes on species richness, diversity, and composition of the herbaceous layer. All the three tree species have greatly increased species richness and diversity both within and outside their crown zones compared with the open grassland. Both species richness and diversity were found to be higher under all the three tree species than outside their crowns, which was in turn higher than the open field. Daniella oliveri has the highest species richness and diversity both within and outside its crown zone followed by Vitellaria paradoxa and then Parkia biglobosa. The result also revealed that the same tree species with different sizes leads to different herbaceous species richness, diversity, and composition under and around the trees' crowns. P. biglobosa and V. paradoxa trees with smaller sizes showed higher species richness and diversity under their crowns than the bigger ones. The dissimilarity of species composition differs between the inside and outside crown zones of the individuals of the same tree species and among the different trees species and the open field.
\end{abstract}

\section{Introduction}

Vegetation with its biodiversity is a crucial part of the Earth Systems (soil, water, and atmosphere), offering essential services to both the ecosystem and human societies [1]. Vegetation supports the functions of soil, which include decomposition, nutrient cycling, soil respiration, invasion resistance, and ecosystem stability. Soil biodiversity in turn provides many ecosystem services essential to mankind and the environment, such as the support of primary production, control of pests and diseases for man and his animals and crops, and the avoidance of environmental contamination through cycling of dead biomass. Also, soil biota plays a significant role in determining the soil physicochemical properties. Plants, in particular, play an important role in shaping soil profile with the diverse architecture of their root systems, being the center of soil-plant-microbial interactions [2].

Vegetation also contributes significantly to the control of soil erosion, which is a serious threat to ecosystem functioning in many parts of the world. It was reported that the magnitude of impact of plants in rendering ecosystem services, particularly in controlling soil erosion, depends on structural architecture of the plant's morphologies (roots systems, crown shape and size, etc.), which in turn depends on the species [3-6]. Hence, diversity within vegetation has been shown to have remarkable effects on ecosystem functions and stability. More often, increasing biodiversity enhanced ecosystem productivity and stability. For example, Seitz et al. [6] report that tree monocultures in afforestation have only limited mitigation potential for soil losses and that there is growing evidence that higher species richness can reduce soil erosion.

Vegetation is also of crucial benefits to the human societies. Many authors report the effectiveness of vegetation in protecting man-made structures like roads, embankments, man-made dams, and pastures that support a significant part of food production, and so forth [1,7]. It is then of great importance to understand the consequences of the worldwide losses of plant species diversity for the ecosystem services in many parts of the world. Of fundamental importance 
amongst these are issues of biodiversity, biofuels/energy security, climate change, food security, human enterprises, land degradation, and water security $[1,2,6]$.

The importance of vegetation in controlling soil erosion, protecting water resources, and supporting carbon cycle has been widely reported. In controlling soil erosion, vegetation is described as the key factor in the processes. Hence, many agroenvironments get protection against top soil loss from surrounding vegetation and intercropping, safe-guarding food production, and security worldwide [8].

Vegetation also plays an important role in water and sediment dynamics of rivers downstream. It has a significant impact on the water and sediment transport in headwater catchments because the vegetation attributes can cause obstructions which generate drag on the flowing water. This drag slows water discharge and reduces the stream flow velocity which in turn influences the sediment dynamics of the flow. This hydrological response happens also as a result of the vegetation ability to enhance infiltration thereby reducing crusting in the soil surface [9-11]. Hence, vegetation was found to protect water bodies like dams, streams, and rivers from sediment for the benefits of human societies in particular and the ecosystem in general [12-14].

Vegetation also contributes immensely to stocking of soil organic carbon, which is essential for good soil structure and nutrient availability that support the soil biota and aboveground productivity. Higher organic carbon concentration and storage were reported under vegetated lands compared with those in bare fields $[15,16]$.

The vegetation in the drier tropical savannas is patchy in distribution with high plant cover (shrub patches) interspersed in a low-cover herbaceous matrix (intershrub areas). This is the result of spatial heterogeneity in local topography and soil microtopography, physicochemical properties, and water distribution [17]. The result is that there are wide ranges of variabilities of the ecosystem services from different local or microenvironment. For example, Cerdà [18] reported that vegetated patches have positively affected surface runoff, erosion, infiltration rates, and deep wetting fronts compared with bare patches. For this reason, different plant communities differ in their resistance to land degradation, and land degradation is thus highly variable among areas [19].

Trees create a unique microenvironment around them [20] by positively modifying their underneath soil physicochemical properties and by direct influence on sunlight and atmospheric conditions [21]. Transpiration and canopy are the main factors affecting air temperature, wind speed, the quantity and quality of light, and soil temperature, $\mathrm{pH}$, moisture, and nutrient availability [22]. The change in soil physicochemical properties depends on the litter quality and quantity and the canopy architecture, which in turn depends on the tree species [23]. As different species of the herbaceous layer respond differently to soil nutrient status and other environmental constraints, the trees are then seen as one of the main factors that influence understory floristic species richness, diversity, and composition. These lead to the notion of zone of influence or ecological fields created by individual trees, especially those with isolated canopy in the savannah $[22,24]$.
The tree crown interacts with solar radiation through absorption and scattering. These processes vary with the leaf structure, size, shape, orientation, distribution, and age and density of the leaf layers, as well as crown volume [25]. All these critical parameters are different among different tree species and individuals of the same species with different age or size [25-28]. Light availability generally affects plant performance but the degree and pattern of these effects may be species specific $[22,29]$. Limiting light availability also helps maintain soil moisture [30]. In this regard, trees have strong filtering ability, which determines the patterns floristic composition of the herbaceous layer [31, 32].

There are also considerable differences in the pattern of rainfall reaching the ground in many plant communities, because of the interception by the tree crown. The water may be subsequently transferred to the soil by channeling down the main stem or by dripping from the branches. The stem flow is greatly enhanced by branches and leaves, which are inclined upward. Stem flow produces a great concentration of water around the base of the trunk, which may be significant ecologically. These morphological features may be powerful ecological factor in plant distribution [25]. Interception of rainfall by trees and the subsequent stem flow induces pattern of soil wetting nearby, for smaller plants [33]. An enhanced concentration of water and nutrients creates favorable microenvironments, which in turn enhances the establishment, growth, and persistence of the herbs beneath $[20,21]$.

Trees also tend to affect properties of soil around them through litter-fall input, which are relative to the tree species and individual sizes [21, 34, 35]. Studies revealed that soils were sandier and slightly acidic under canopies of medium and large trees compared to small trees, which have slightly alkaline soils. Soils in the tree interspaces have significantly higher silt and clay content than beneath trees [36]. Thus, distribution of general soil fertility, organic matter, nitrogen, phosphorus, and potassium, as well as microbial activities, becomes spatially and vertically concentrated under the tree canopy [20]. Elsewhere, soils under canopies were found to have significantly higher levels of organic matter, calcium, magnesium, and $\mathrm{pH}$ than those in open grassland [34].

The general patterns of response of herbaceous layer under tree canopy to increase in nutrient availability, especially nitrogen, often include initial increase in cover layer as a whole, decrease in species richness from loss of relatively numerous nitrogen-efficient species, and decrease in species evenness from increasing dominance of few high nitrogenrequiring species [29, 37]. However, the effects of trees on the associated understory herbaceous productivity vary with the environment or the climatic conditions [38]. In addition, different herbaceous plant species will respond differently to different types of tree canopies; therefore, results of study from one area with specific tree species cannot be extrapolated to other areas with different trees and herbaceous plant species composition.

Although numerous studies have demonstrated that the species composition and diversity of understory flora can be influenced by tree canopy [39], such a study is almost virtually absent in the Nigerian dry lands. This study was 
carried out to find the impacts of different tree species and individuals of different sizes on composition, richness, and diversity of the herbaceous layer. The findings of such studies are indispensable tool in conservation and management of practices of grasslands. The information on the pattern of impact of trees on their environment will be beneficial in restoring diversity in the dry lands, especially with regard to choosing tree species for reforestation or afforestation programmes.

The general aim of this study was to find how tree species affect the composition of the herbaceous layer underneath; specifically, to find whether different tree species affect the underneath herbaceous composition in different ways; and also to find whether individuals of the same trees species but of different sizes affect the herbaceous layer in different way in terms of species composition, richness, and diversity.

\section{Methodology}

2.1. Study Area. The study area was the Yelwa campus of Abubakar Tafawa Balewa University, Bauchi, located at latitude 100 17I North, longitude 80 49I East, at the altitude of $690.2 \mathrm{M}$ above sea level in the northern guinea savanna ecological zone of Nigeria [40]. The soils here are generally classified as Alfisols [41]. The soil is highly weathered and fragile with low activity clays, thus making their fertility decline under continuous arable cropping. The excessive soil nutrient mining and degradation have been reported to be one of the most biogeophysical constraints in this region [42]. The climate is characterized by rainy season that starts in April and ends in October, with the amount of rainfall of $1300 \mathrm{~mm}$ per annum [43], with the lowest mean monthly relative humidity at about $29 \%$ [44]. The month of April is the hottest month of the year with mean minimum and maximum temperature of $13.7^{\circ} \mathrm{C}$ and $30.11^{\circ} \mathrm{C}$, respectively [45]. The vegetation type is open woodland, dominated with tall grasses ranges between one and three meters $(\mathrm{m})$ high in open areas and trees (up to $15 \mathrm{~m}$ high) usually with short boles, broad leaves, and isolated crowns. This vegetation is subjected to fierce wild fires almost annually in the dry season. It is therefore predominated by fire-resistant species [44]. Species such as Isoberlinia doka and I. tomentosa form the bulk of the scattered woodland in the northern guinea savannah. Also found are locust bean tree (Parkia biglobosa) and shea butter tree (Vitellaria paradoxa) [46].

2.2. Floristic Data Collection. The tree species used in this study were Parkia biglobosa (Jacq.) Benth., Daniella oliveri (Rolfe) Hutch. \& Dalziel, and Vitellaria paradoxa C.F. Gaertn. To collect the floristic data, the circumference of each tree crown zone was roughly divided into three sections, that is, $120^{\circ}$ sectors. The dividing lines of the sectors were extended to the distance of 3 meters outside the crown zone from the base of the main stem (Figure 1). A quadrat of size 50 by $50 \mathrm{~cm}$ was laid at a standard distance of one meter from the main stem along each of the three dividing lines of the crown zone. The sampling was repeated at the distance of two meters away from the crown zone, but still on the lines of divisions. Thus, there were three samples within the

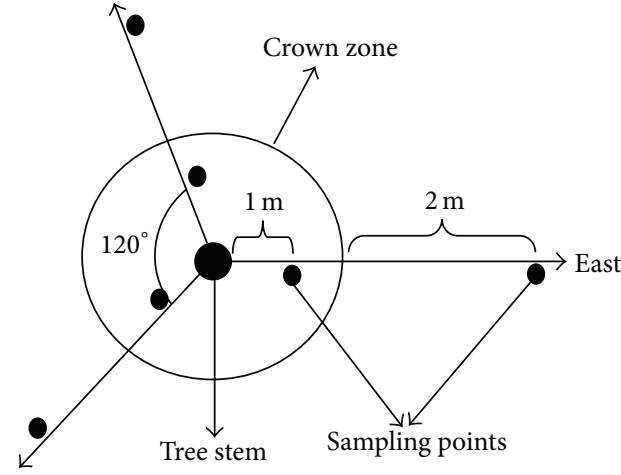

FIGURE 1: Diagram of the sampling design.

TABLE 1: The sizes of the individual trees that were used in the study for comparison.

\begin{tabular}{lcc}
\hline Tree species & $\begin{array}{c}\text { Big tree } \\
\text { Crown diameter }\end{array}$ & $\begin{array}{c}\text { Small tree } \\
\text { Crown diameter }\end{array}$ \\
\hline \multirow{2}{*}{. paradoxa } & $16.6 \mathrm{~m}$ & $8.8 \mathrm{~m}$ \\
& $14.5 \mathrm{~m}$ & $8.3 \mathrm{~m}$ \\
& $12.4 \mathrm{~m}$ & $7.7 \mathrm{~m}$ \\
\hline \multirow{3}{*}{ biglobosa } & $20 \mathrm{~m}$ & $13.6 \mathrm{~m}$ \\
& $24.5 \mathrm{~m}$ & $12.4 \mathrm{~m}$ \\
& $20.1 \mathrm{~m}$ & $12.8 \mathrm{~m}$ \\
\hline
\end{tabular}

crown zone and three outside the crown zone of each tree. The sampling was repeated for five individual trees of the same species, that is, fifteen samples each for within and outside crown zones of each tree species. Fifteen samples were also taken from the open field, which was a distance of at least more than 10 meters away from the nearest tree. The number of individuals of each plants species within the quadrat was recorded. In addition, specimens of each species were collected and subsequently identified in the Abubakar Tafawa Balewa University herbarium.

To compare the impact of tree size on the understory herbaceous layer, some individuals of $V$. paradoxa and $P$. biglobosa were subjectively categorized based on their sizes as big and small for the purpose of this study, but $D$. oliveri were not categorized on sizes because they were found to be almost of the same size (Table 1). To estimate their sizes, the averages of the shortest and the longest axis of the tree crown diameter were measured in meters. Tree crown diameter is known to be directly proportional to the overall size of the tree and therefore good estimate of the tree size $[47,48]$.

2.3. Data Analyses. All plant species parameters were calculated using the software Community Ecology Parameter Calculator (ComEcoPaC) Version 1.0 [49]. According to the designer, formulae used by this software were as follows.

Shannon-Wiener Diversity Index $\left(H^{\prime}\right)$. The Shannon-Wiener Diversity Index $\left(H^{\prime}\right)$ is as follows:

$$
H^{\prime}=\sum_{i=1}^{S} p_{i} \cdot \log _{2} p_{i}
$$


TABLE 2: Species richness, diversity, and evenness from inside and outside crown zones and the open field, with the estimates of their standard deviation (StDev) and Standard Error of the Mean (SE Mean). PB: P. biglobosa; DO: D. oliveri; VP: V. paradoxa.

\begin{tabular}{lccccccccc}
\hline & PB inside & PB outside & DO inside & DO outside & VP inside & VP outside & Open field & SE Mean & StDev \\
\hline Species richness & 31 & 33 & 39 & 38 & 31 & 29 & 20 & 2.39 & 6.32 \\
Shannon Index & 3.92 & 3.34 & 4.16 & 3.73 & 3.69 & 3.38 & 3.39 & 0.117 & 0.31 \\
Evenness & 0.79 & 0.66 & 0.79 & 0.71 & 0.74 & 0.7 & 0.78 & 0.0192 & 0.0508 \\
\hline
\end{tabular}

TABLE 3: Half matrix of dissimilarity of species composition among inside and outside crown zones of the trees and the open field. PB: $P$. biglobosa; DO: D. oliveri; VP: V. paradoxa.

\begin{tabular}{|c|c|c|c|c|c|c|}
\hline Jaccard's similarity index & PB outside & DO inside & DO outside & VP inside & VP outside & Open field \\
\hline PB inside & 0.55 & 0.48 & 0.53 & 0.56 & 0.5 & 0.62 \\
\hline PB outside & & 0.36 & 0.42 & 0.55 & 0.32 & 0.57 \\
\hline DO inside & & & 0.29 & 0.48 & 0.49 & 0.63 \\
\hline DO outside & & & & 0.47 & 0.4 & 0.51 \\
\hline VP inside & & & & & 0.5 & 0.54 \\
\hline VP outside & & & & & & 0.47 \\
\hline
\end{tabular}

where $S$ is the species richness (number of species), $p_{i}$ is the proportion of species $i$, and $p_{i}=n_{i} / N\left(n_{i}\right.$ is the abundance of species $i ; N$ is the total abundance).

Evenness (E). Evenness is represented as follows:

$$
E=\frac{H^{\prime}}{H_{\max }},
$$

where $H_{\max }^{\prime}=\log _{2} S$ and $H_{\min }^{\prime}=-((N-S+1) / N) \log _{2}((N-$ $S+1) / N)+((S-1) / N) \log _{2} N$.

Jaccard's Similarity Index. Jaccard's similarity index is represented as follows:

$$
\mathrm{Ja}=\frac{S_{12}}{S_{1}+S_{2}-S_{12}},
$$

where $S_{12}$ is the number of species present in both samples (joint occurrences) and $S_{1}\left(S_{2}\right)$ is the number of species present in sample one (sample two).

Jaccard's dissimilarity index $=1-$ similarity index [50].

One-Sample t-Test was carried out toestimate standard deviation and Standard Error of the Mean for all the species parameters using Minitab version 17.2.1 (C)2013, 2015 Minitab., Inc.).

\section{Result}

The result revealed that all the three tree species have greatly increased species richness both within and outside their crown zones, which ranged from 31 to 39 compared with the open field, which was just 20 (Table 2). D. oliveri has the highest species richness both within and outside its crown zone followed by $V$. paradoxa and then P. biglobosa. There were a slightly higher number of species inside than outside crown zones of all the trees. Species diversity also was found to be higher inside than outside crown zones of all the trees and the open field. Species diversity was highest under $D$. oliveri. Species evenness seems to be unaffected by the trees.

The dissimilarity of species composition differs between the inside and outside crown zones of the individuals of the same tree species and among the different trees species and the open field (Table 3). Higher dissimilarity was found between the inside and outside crown zone of P. biglobosa (0.55). The least dissimilarity was between the inside and outside crown zone of $D$. oliveri (0.29), while for that of $V$. paradoxa the value was 0.5 . Comparisons between the open field and the inside and outside crown zones of all the tree species also revealed great differences in the species composition. The values range from 0.47 to 0.63 . However, higher dissimilarities were found between the open field and the inside crown zones than the outside of crown zones of all the tree species.

The study also showed that species richness was slightly higher in the inside and outside crown zones of individual trees with small size compared with the big trees of $P$. biglobosa and $V$. paradoxa (Table 4). Higher species diversity was also found to be associated with both inside and outside crown zone of small $P$. biglobosa compared with bigger ones while, for inside crown zone of $V$. paradoxa, higher diversity was found with big trees than small trees. However, there was higher diversity outside crown zone of small $\mathrm{V}$. paradoxa compared to the bigger ones.

The similarity or dissimilarity of understory herbaceous species composition also differs with different tree sizes (Table 5). The dissimilarity value between the inside crown zones of big and small $V$. paradoxa was 0.5 , while the outside crown zones have dissimilarity of 0.66 . In P. biglobosa, dissimilarity value between the inside crown zones of big and small individual trees was 0.62 , while the outside crown zones of big and small trees have dissimilarity value of 0.33 .

\section{Discussion}

It is already well documented that trees affect their environment through shading, rainfall interception, interference 
TABLE 4: Species richness, diversity, and evenness from inside and outside crown zones of trees with different sizes and the open field, with their standard deviation (StDev) and Standard Error of the Mean (SE Mean). PB: P. biglobosa; VP: V. paradoxa.

\begin{tabular}{lcccccccccc}
\hline & $\begin{array}{c}\text { Small } \\
\text { VP } \\
\text { inside }\end{array}$ & $\begin{array}{c}\text { Small } \\
\text { VP } \\
\text { outside }\end{array}$ & $\begin{array}{c}\text { Big VP } \\
\text { inside }\end{array}$ & $\begin{array}{c}\text { Big VP } \\
\text { outside }\end{array}$ & $\begin{array}{c}\text { Small } \\
\text { PB } \\
\text { inside }\end{array}$ & $\begin{array}{c}\text { Small } \\
\text { PB } \\
\text { outside }\end{array}$ & $\begin{array}{c}\text { Big PB } \\
\text { inside }\end{array}$ & $\begin{array}{c}\text { Big PB } \\
\text { outside }\end{array}$ & SE Mean & StDev \\
\hline Species richness & 26 & 24 & 25 & 22 & 23 & 28 & 21 & 27 & 0.866 & 2.449 \\
Shannon Index & 3.43 & 3.15 & 3.77 & 3.12 & 3.72 & 3.26 & 2.47 & 2.98 & 0.148 & 0.419 \\
Evenness & 0.73 & 0.69 & 0.81 & 0.70 & 0.82 & 0.68 & 0.56 & 0.63 & 0.0306 & 0.0865 \\
\hline
\end{tabular}

TABLE 5: Half matrix of similarity and dissimilarity (in parenthesis) of species composition among inside and outside crown zones of the tree of different sizes. PB: P. biglobosa; DO: D. oliveri; VP: V. paradoxa.

\begin{tabular}{|c|c|c|c|c|c|c|c|}
\hline Jaccard's similarity index & $\begin{array}{c}\text { Small VP } \\
\text { outside }\end{array}$ & $\begin{array}{c}\text { Big VP } \\
\text { inside }\end{array}$ & $\begin{array}{l}\text { Big VP } \\
\text { outside }\end{array}$ & $\begin{array}{c}\text { Small PB } \\
\text { inside }\end{array}$ & $\begin{array}{c}\text { Small PB } \\
\text { outside }\end{array}$ & $\begin{array}{l}\text { Big PB } \\
\text { inside }\end{array}$ & $\begin{array}{l}\text { Big PB } \\
\text { outside }\end{array}$ \\
\hline Small VP inside & $0.43(0.57)$ & $0.5(0.5)$ & $0.33(0.77)$ & $0.4(0.6)$ & $0.38(0.62)$ & $0.47(0.53)$ & $0.43(0.67)$ \\
\hline Small VP outside & & $0.53(0.47)$ & $0.44(0.66)$ & $0.52(0.48)$ & $0.49(0.51)$ & $0.36(0.64)$ & $0.46(0.54)$ \\
\hline Big VP inside & & & $0.57(0.43)$ & $0.45(0.55)$ & $0.56(0.44)$ & $0.44(0.66)$ & $0.53(0.47)$ \\
\hline Big VP outside & & & & $0.41(0.59)$ & $0.56(0.44)$ & $0.39(0.61)$ & $0.58(0.42)$ \\
\hline Small PB inside & & & & & $0.42(0.58)$ & $0.38(0.62)$ & $0.47(0.53)$ \\
\hline Small PB outside & & & & & & $0.32(0.68)$ & $0.67(0.33)$ \\
\hline Big PB inside & & & & & & & $0.37(0.63)$ \\
\hline
\end{tabular}

with light penetration, and the quantity and quality of litter they produce that change soil physical and chemical properties. The amount of these impacts through interference with sunlight availability and soil nutrient amplification also depends on the tree species and size of the individual [51]. This brings about improved soils fertility and structure below their crowns; improved water relations of plants in their shades; and increased competition for light, soil moisture, and nutrients in the herb layer, which generates spatial environmental heterogeneity at different scales. The spatial variability of microenvironments created by the trees leads to differences in floristic parameters of the herbaceous layer [52], because plant species respond individualistically to environmental variables and, therefore, to tree influences [53, 54]. The nature and intensity of the effect of these trees may also depend on their leaf area, canopy architecture, patterns rooting system, and so forth, which in turn depend on the tree species in question $[51,53]$.

In this study, all the trees were also found to affect the distribution and composition of herbaceous layer under and around their crowns in comparison with the open field. There were increased species richness and diversity under and outside the trees canopy, which was greater than that of the open field. In contrast, some studies suggested that the response of herbaceous layer under tree canopy led to decrease in species richness and diversity because increase in soil nitrogen input will lead to the loss of many nitrogenefficient species which brings about dominance of few high nitrogen-requiring species [29, 37]. Studies in a forest by Vockenhuber et al. [55] also showed a negative response of species richness to increasing canopy cover.

This study also revealed that the impacts of the trees on herbaceous species richness and diversity are different under different tree species. In the increasing order of impact, the trees are Parkia biglobosa, Vitellaria paradoxa, and Daniella oliveri. This order was also observed to be relative to the size of their crowns (cover) in decreasing order. This means that the greater the crown size or cover, the lesser the species richness and diversity under them. Here, the implication in terms of light availability is that the smaller crowns will allow more sunlight to reach the ground in the midday and allow full sunlight under them in the morning and evening. Many studies also revealed increased species richness of the herb layer with increasing tree diversity. This is because herbaceous layer responds differently to different microenvironment created by different tree species, that is, by increasing environmental heterogeneity or by creating environmental conditions that are favourable to a greater number of the herbaceous species $[52,55]$.

It is also interesting to note that species richness and diversity were found to be higher under all the three tree species than outside their crowns. However, reduction of light intensity by tree crown was known to suppress productivity in many agricultural experiments. The influence of trees on species richness and diversity is considered to be associated with two most important factors: the altered soil conditions and light levels [56]. It is also important to note that, in almost all studies on the impact of trees on herb layer, no quantitative measurements are taken on the tree crowns and the light they intercept was not quantified. Hence, interpretation of the response of the herbaceous layer remains largely subjective.

The tree size was also known to be a factor that determines degree of the tree impact on the trees' environments $[53,54]$. In the savanna, where trees grow with isolated crowns, trees with smaller crown size will be expected to receive more or full sunlight under their canopy than trees with bigger crown 
diameter, especially in the morning and evening. In this study, $P$. biglobosa and $V$. paradoxa trees with smaller sizes showed higher species richness and diversity under their crowns than the bigger ones. Again, small trees are expected to have less nutrient availability and greater sunlight penetration under their crowns [54]. These suggest that abundance of sunlight may reduce or suppress dominance by few high nutrient-requiring species because of increase in competitive ability of the species that are sun lover with low nutrient demand. The combine effects of optimal nutrient availability and sunlight may be the factors that bring about increase of species richness and diversity. Some studies also reported that smaller trees have a different effect on the understory vegetation than large trees or open grassland [57].

Different plant species have different optimal environmental requirement and also different local environmental conditions were created by different tree species or the same tree species but with different sizes. Each of these heterogeneous microhabitats that are specific for each tree species and size will be optimal or near optimal for some species of the grass layer but not others. The response of the herbaceous layer to sunlight and nutrient availability is also species specific. One species will find the environment more suitable than others will; hence, the most favored species will outperform the less favored ones. Therefore, different microenvironment created by different tree species or by individuals of different sizes will be occupied by combination of different species with different degree of abundance. It is therefore expected that herbaceous species composition will differ with respect to tree species and size and the open grassland, which is in agreement with Ludwig et al. [54]. It has also been suggested by Vockenhuber et al. [55] that the environmental heterogeneity created by higher tree diversity may lead to higher small-scale heterogeneity of site conditions and consequently to higher herbaceous species diversity.

The three tree species used in this study create herbaceous plant communities with different species composition underneath and around their crown zones. Also, the same tree species of different sizes of individual also created different herbaceous species composition beneath their crown. This means that the ground herbaceous layer also responded in a different way in combination and relative abundance with respect to the trees' microenvironment created by different tree species leading to high dissimilarity values among the three tree species. Elsewhere, studies showed that species composition of the herbaceous layer might change along gradients extending from the bole to the canopy and the open grassland $[53,56]$.

Finally, this study revealed that different tree species with different sizes lead to different herbaceous species richness, diversity, and composition under and around their crowns. However, generally, studies on tree-grass interactions in savannas should include consideration of elements of competition and facilitation by the trees, climate and seasonal variability, stages of succession, soil type, tree density, and varying other biotic and abiotic complexities in both time and space $[52,53]$. Therefore, the result of this study is not conclusive.

\section{Conclusion}

All the three tree species have greatly increased species richness and diversity both within and outside their crown zones compared with the open grassland. Both species richness and diversity were found to be higher under all the three tree species than outside their crowns, which was higher than the open field. D. oliveri has the highest species richness and diversity both within and outside its crown zone followed by $V$. paradoxa and then P. biglobosa. The result also revealed that the same tree species with different sizes leads to different herbaceous species richness, diversity, and composition under and around the trees' crowns. P. biglobosa and $V$. paradoxa trees with smaller sizes showed higher species richness and diversity under their crowns than the bigger ones. The dissimilarity of species composition also differs between the inside and outside crown zones of the individuals of the same tree species and among the different tree species and the open field.

\section{Conflict of Interests}

The author declares that there is no conflict of interests regarding the publication of this paper.

\section{Acknowledgment}

The author is most grateful to the Department of Biological Sciences of the Abubakar Tafawa Balewa University for providing some measuring equipment that was used in this study.

\section{References}

[1] F. Berendse, J. Van Ruijven, E. Jongejans, and S. D. Keesstra, "Loss of plant species diversity reduces soil erosion resistance of embankments that are crucial for the safety of human societies in low-lying areas," Ecosystems, vol. 18, no. 5, pp. 881-888, 2015.

[2] E. C. Brevik, A. Cerdà, J. Mataix-Solera et al., "The interdisciplinary nature of SOIL," SOIL, vol. 1, no. 1, pp. 117-129, 2015.

[3] A. Cerdà and S. H. Doerr, "Influence of vegetation recovery on soil hydrology and erodibility following fire: an 11-year investigation," International Journal of Wildland Fire, vol. 14, no. 4, pp. 423-437, 2005.

[4] J.-W. Lee, C.-M. Park, and H. Rhee, "Revegetation of decomposed granite roadcuts in Korea: developing digger, evaluating cost effectiveness, and determining dimensions of drilling holes, revegetation species, and mulching treatment," Land Degradation and Development, vol. 24, no. 6, pp. 591-604, 2013.

[5] E. Bochet, "The fate of seeds in the soil: a review of the influence of overland flow on seed removal and its consequences for the vegetation of arid and semiarid patchy ecosystems," SOIL, vol. 1, no. 1, pp. 131-146, 2015.

[6] S. Seitz, P. Goebes, Z. Song et al., "Tree species identity and functional traits but not species richness affect interrill erosion processes in young subtropical forests," SOIL Discuss, vol. 2, no. 1, pp. 701-736, 2015.

[7] K. E. Seutloali and H. R. Beckedahl, "Understanding the factors influencing rill erosion on roadcuts in the south eastern region of South Africa," Solid Earth, vol. 6, no. 2, pp. 633-641, 2015. 
[8] J. Lieskovský and P. Kenderessy, "Modelling the effect of vegetation cover and different tillage practices on soil erosion in vineyards: a case study in vráble (Slovakia) using WATEM/SEDEM," Land Degradation and Development, vol. 25, no. 3, pp. 288-296, 2014.

[9] S. D. Keesstra, E. Kondrlova, A. Czajka, M. Seeger, and J. Maroulis, "Assessing riparian zone impacts on water and sediment movement: a new approach," Netherlands Journal of Geosciences, vol. 91, no. 1-2, pp. 245-255, 2012.

[10] M. A. Gabarrón-Galeote, J. F. Martínez-Murillo, M. A. Quesada, and J. D. Ruiz-Sinoga, "Seasonal changes in the soil hydrological and erosive response depending on aspect, vegetation type and soil water repellency in different Mediterranean microenvironments," Solid Earth, vol. 4, no. 2, pp. 497-509, 2013.

[11] M. Mekonnen, S. D. Keesstra, J. E. Baartman, C. J. Ritsema, and A. M. Melesse, "Evaluating sediment storage dams: structural off-site sediment trapping measures in northwest Ethiopia," Cuadernos de Investigación Geográfica, vol. 41, no. 1, pp. 7-22, 2015.

[12] A. Cerdà, "The influence of aspect and vegetation on seasonal changes in erosion under rainfall simulation on a clay soil in Spain," Canadian Journal of Soil Science, vol. 78, no. 2, pp. 321330, 1998.

[13] A. Cerdà, "The influence of geomorphological position and vegetation cover on the erosional and hydrological processes on a Mediterranean hillslope," Hydrological Processes, vol. 12, no. 4, pp. 661-671, 1998.

[14] A. Cerdà and S. H. Doerr, "The effect of ant mounds on overland flow and soil erodibility following a wildfire in eastern Spain," Ecohydrology, vol. 3, no. 4, pp. 392-401, 2010.

[15] S. K. Barua and S. M. S. Haque, "Soil characteristics and carbon sequestration potentials of vegetation in degraded hills of Chittagong, Bangladesh," Land Degradation and Development, vol. 24, no. 1, pp. 63-71, 2013.

[16] Debasish-Saha, S. S. Kukal, and S. S. Bawa, "Soil organic carbon stock and fractions in relation to land use and soil depth in the degraded Shiwaliks hills of lower Himalayas," Land Degradation and Development, vol. 25, no. 5, pp. 407-416, 2014.

[17] A. I. Kröpfl, G. A. Cecchi, N. M. Villasuso, and R. A. Distel, "Degradation and recovery processes in semi-arid patchy rangelands of Northern Patagonia, Argentina," Land Degradation and Development, vol. 24, no. 4, pp. 393-399, 2013.

[18] A. Cerdà, "The effect of patchy distribution of Stipa tenacissima L. on runoff and erosion," Journal of Arid Environments, vol. 36, no. 1, pp. 37-51, 1997.

[19] R. G. Palacio, A. J. Bisigato, and P. J. Bouza, "Soil erosion in three grazed plant communities in Northeastern Patagonia," Land Degradation and Development, vol. 25, no. 6, pp. 594-603, 2014.

[20] R. E. Munn, Ecosystem Experiments, John Wiley \& Sons, New York, NY, USA, 1991.

[21] A. Moody and J. A. Jones, "Soil response to canopy position and feral pig disturbance beneath Quercus agrifolia on Santa Cruz Island, California," Applied Soil Ecology, vol. 14, no. 3, pp. 269281, 2000.

[22] A. Zemmrich, M. Manthey, S. Zerbe, and D. Oyunchimeg, "Driving environmental factors and the role of grazing in grassland communities: a comparative study along an altitudinal gradient in Western Mongolia," Journal of Arid Environments, vol. 74, no. 10, pp. 1271-1280, 2010.

[23] S. E. Macdonald and T. E. Fenniak, "Understory plant communities of boreal mixedwood forests in western Canada: natural patterns and response to variable-retention harvesting," Forest Ecology and Management, vol. 242, no. 1, pp. 34-48, 2007.

[24] F. Ludwig, H. De Kroon, H. H. T. Prins, and F. Berendse, "Effects of nutrients and shade on tree-grass interactions in an East African savanna," Journal of Vegetation Science, vol. 12, no. 4, pp. 579-588, 2001.

[25] J. L. Monteith, Vegetation and the Atmosphere, Academic Press, London, UK, 1975.

[26] N. J. Rosenberg, Miroclimate: The Biological Environment, John Wiley \& Sons, New York, NY, USA, 1974.

[27] P. Bengtson, U. Falkengren-Grerup, and G. Bengtsson, "Spatial distributions of plants and gross $\mathrm{N}$ transformation rates in a forest soil," Journal of Ecology, vol. 94, no. 4, pp. 754-764, 2006.

[28] E. Ayres, H. Steltzer, S. Berg, M. D. Wallenstein, B. L. Simmons, and D. H. Wall, "Tree species traits influence soil physical, chemical, and biological properties in high elevation forests," PLoS ONE, vol. 4, no. 6, Article ID e5964, 2009.

[29] F. S. Gilliam, "Response of the herbaceous layer of forest ecosystems to excess nitrogen deposition," Journal of Ecology, vol. 94, no. 6, pp. 1176-1191, 2006.

[30] S. Reed, Environment and Security, Climate Institute, 2007, http: //www.climate.org/topics/environmental-security/index.html.

[31] J. M. Fraterrigo, M. G. Turner, and S. M. Pearson, "Previous land use alters plant allocation and growth in forest herbs," Journal of Ecology, vol. 94, no. 3, pp. 548-557, 2006.

[32] S. Kukshal, B. P. Nautiyal, A. Anthwal, A. Sharma, and A. B. Bhatt, "Phytosociological investigation and life form pattern of grazinglands under pine canopy in temperate zone, Northwest Himalaya, India," Research Journal of Botany, vol. 4, no. 2, pp. 55-69, 2009.

[33] W. D. Goodall and R. A. Perry, Arid Land Ecosystems, vol. 2, Cambridge University Press, London, UK, 1981.

[34] A. O. Isichei and J. I. Muoghalu, "The effects of tree canopy cover on soil fertility in a Nigerian savanna," Journal of Tropical Ecology, vol. 8, no. 3, pp. 329-338, 1992.

[35] L. Zhang, X. Mi, H. Shao, and K. Ma, "Strong plant-soil associations in a heterogeneous subtropical broad-leaved forest," Plant and Soil, vol. 347, no. 1, pp. 211-220, 2011.

[36] D. Mlambo, P. Nyathi, and I. Mapaure, "Influence of Colophospermum mopane on surface soil properties and understorey vegetation in a southern African savanna," Forest Ecology and Management, vol. 212, no. 1-3, pp. 394-404, 2005.

[37] A. J. Belsky, "Influences of trees on savanna productivity: tests of shade, nutrients, and tree-grass competition," Ecology, vol. 75, no. 4, pp. 922-932, 1994.

[38] H. C. Kahi, R. K. Ngugi, S. M. Mureithi, and J. C. Ng'ethe, "The canopy effects of Prosopis juliflora (DC) and Acacia tortilis (Hayne) trees on herbaceous plants species and soil physico-chemical properties in Njemps Flats, Kenya,' Tropical and Subtropical Agroecosystems, vol. 10, no. 3, pp. 441-449, 2009.

[39] H. Huo, Q. Feng, and Y.-H. Su, “The influences of canopy species and topographic variables on understory species diversity and composition in coniferous forests," The Scientific World Journal, vol. 2014, Article ID 252489, 8 pages, 2014.

[40] D. Zahraddeen, I. S. R. Butswat, and L. S. Taimako, "Assessment of reproductive problems in some ruminants under smallholder husbandry system in Bauchi, Nigeria," Continental Journal of Veterinary Science, vol. 4, pp. 1-8, 2010.

[41] A. A. Amba, E. B. Agbo, N. Voncir, and M. O. Oyawoye, "Effect of phosphorus fertilizer on some soil chemical properties and nitrogen fixation of legumes at Bauchi," Continental Journal of Agricultural Science, vol. 5, no. 1, pp. 39-44, 2011. 
[42] B. M. Shehu, J. M. Jibrin, and A. M. Samndi, "Fertility status of selected soils in the Sudan Savanna Biome of Northern Nigeria," International Journal of Soil Science, vol. 10, no. 2, pp. 74-83, 2015.

[43] A. M. Hassan, "Genesis, classification and agricultural potential of the soils derived from Kerrikerri sandstone formation in northern Nigeria," Continental Journal of Agricultural Science, vol. 4, pp. 7-19, 2010.

[44] E. E. Obioha, "Climate variability, environment change and food security nexus in Nigeria," Journal of Human Ecology, vol. 26, no. 2, pp. 107-121, 2009.

[45] A. A. Bose, A. Abdulhamid, and M. Yusuf, "Impact assessment of infrastructures on income of rural farmers' development in Dass local government area of Bauchi State," ATBU Journal of Science, Technology and Education, vol. 2, no. 2, pp. 17-27, 2014.

[46] E. M. Aregheore, Nigeria: Country Pasture/Forage Resource Profiles, FAO, 2009, http://www.fao.org/ag/agp/AGPC/doc/Counprof/ PDF\%20files/Nigeria.pdf.

[47] P. A. Tanka, Prediction of distribution for total height and crown ratio using normal versus other distributions [M.S. thesis], Auburn University, Auburn, Ala, USA, 2006.

[48] S. Turan, "Diameter at breast height-crown diameter prediction models for Picea orientalis," African Journal of Agricultural Research, vol. 4, no. 3, pp. 215-219, 2009.

[49] P. Drozd, ComEcoPaC-Community Ecology Parameter Calculator. Version 1, 2010, http://prf.osu.cz/kbe/dokumenty/sw/ ComEcoPaC/ComEcoPaC.xls.

[50] M. Kent and P. Coker, Vegetation Description and Analysis: A Practical Approach, John Wiley \& Sons, Chichester, UK, 1992.

[51] B. Sharma and K. Sharma, "Influence of various dominant trees on phytosociology of under storey herbaceous vegetation," Recent Research in Science and Technology, vol. 5, no. 2, pp. 4145, 2013.

[52] M. T. Simmons, S. R. Archer, W. R. Teague, and R. J. Ansley, "Tree (Prosopis glandulosa) effects on grass growth: an experimental assessment of above- and belowground interactions in a temperate savanna," Journal of Arid Environments, vol. 72, no. 4, pp. 314-325, 2008.

[53] R. J. Scholes and S. R. Archer, "Tree-grass interactions in Savannas," Annual Review of Ecology and Systematics, vol. 28, pp. 517-544, 1997.

[54] F. Ludwig, H. De Kroon, F. Berendse, and H. H. T. Prins, "The influence of savanna trees on nutrient, water and light availability and the understorey vegetation," Plant Ecology, vol. 170, no. 1, pp. 93-105, 2004.

[55] E. A. Vockenhuber, C. Scherber, C. Langenbruch, M. Meißner, D. Seidel, and T. Tscharntke, "Tree diversity and environmental context predict herb species richness and cover in Germany's largest connected deciduous forest," Perspectives in Plant Ecology, Evolution and Systematics, vol. 13, no. 2, pp. 111-119, 2011.

[56] A. Maginniss, A. Moseman, and J. Noyce, "Variable effects of tree-cover on plant productivity and diversity of forbs and shrubs," Tillers, vol. 3, pp. 21-24, 2002.

[57] F. Ludwig, H. De Kroon, and H. H. T. Prins, "Impacts of savanna trees on forage quality for a large African herbivore," Oecologia, vol. 155, no. 3, pp. 487-496, 2008. 

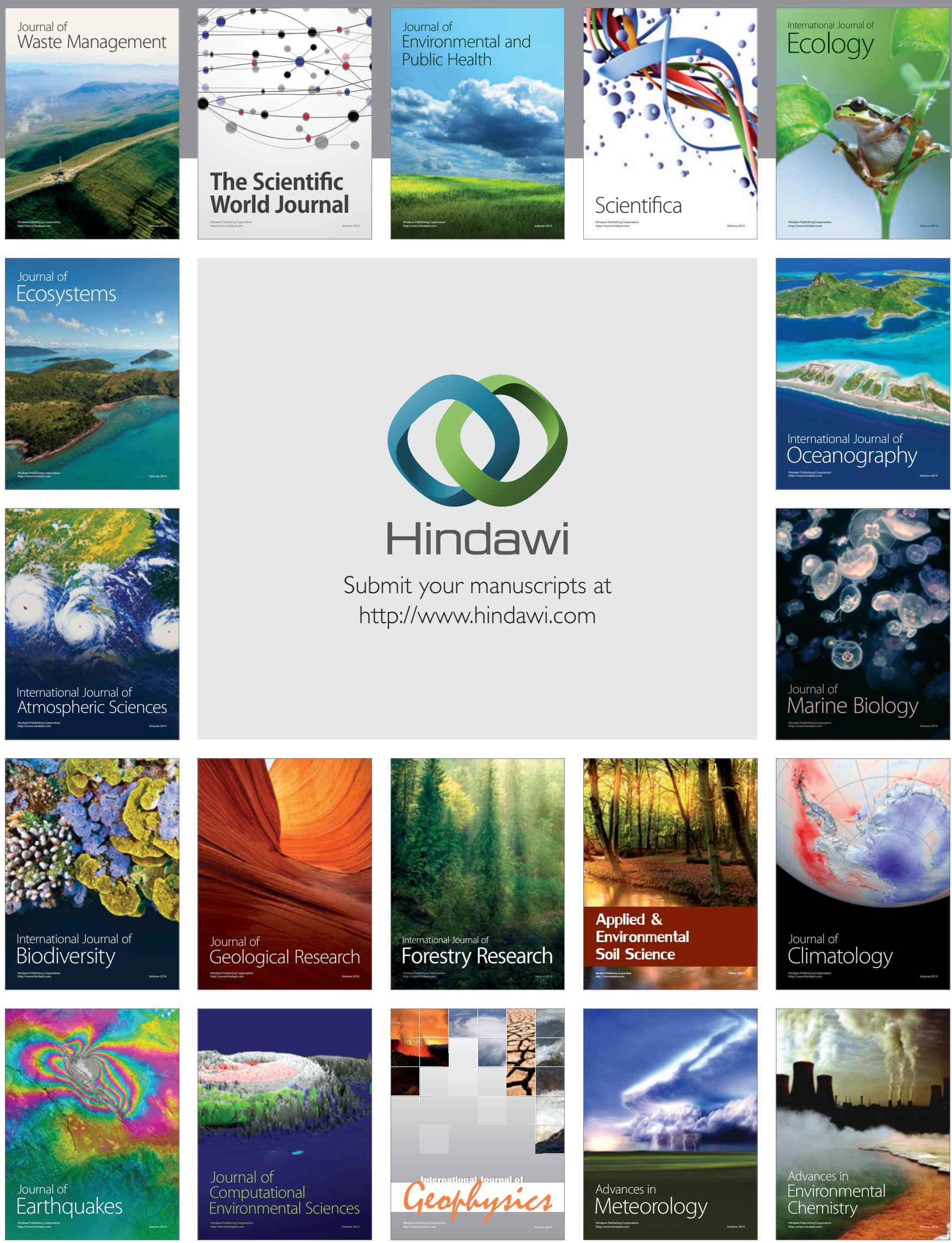